\title{
The Informatization Research on Manufacturing Industry in Northeast
}

\author{
China \\ Jie Qiu, Hai-yang Zhang \\ Harbin University of Science and Technology
}

Key Words: Northeast China; manufacturing industry; informatization

\begin{abstract}
Founding of New China, the manufacturing industry in Northeast China was once the center of China's manufacturing industry, contributing a lot for China's socialist modernization and national economic development. However, since the reform and opening up, the development speed of the manufacturing industry in Northeast China has slowed significantly, whose growth rate remains below national average and subsequently exposes a series of problems. Therefore, in accordance with requirements of the 16th Party Congress, we persist in promoting industrialization by informatization, using IT to propel industrialization and setting out on a new industrialization road characteristic of high technology content, good economic returns, low resource consumption, little environmental pollution and fully used manpower resources advantages. It is not only a good opportunity for the manufacturing industry in Northeast China to get out of the trouble, but also can bring vitality and vigor for its future development.

Introduction: The 21st century is the era of informatization. With the deepening of economic globalization and various countries' economic interdependence degree, the manufacturing industry has become the pillar industry of a country. Therefore, during the process of promoting the manufacturing industry in Northeast China, it is extremely urgent to improve enterprise competitiveness and enhance talent cohesion.
\end{abstract}

\section{I、The Status of Manufacturing Industry Informatization in Northeast China}

The manufacturing industry means processing and reprocessing the raw material(products in extractive industries and agricultural products, which is also the general term of accessories assembly industry and the material basis of national economic, social development and national defense construction. The developmental level of manufacturing industry determines the international division status of one country in the economic globalization trend. At present, along with the accelerating process of economic globalization, the world's manufacturing productivity layout is undergoing profound changes and China is facing an unprecedented historical opportunity to speed up the manufacturing industry. In recent years, China's manufacturing industry is developing rapidly. But the true sense of the "world factory", should be characterized by not only possessing quite a share in industrial markets around the world but also possessing quite a number of innovative products. Now, China's manufacturing industry still has big gap compared to developed countries in the overall size, production capacity and product varieties. It is obviously that the traditional manufacturing industry is faced with serious challenges and new opportunities.

At present, the overall scale of the manufacturing industry in northeast China has begun to take shape, but it still has certain gap compared with the whole country. The technology innovation ability in most enterprises is weak while many key technologies and equipment still rely on foreign 
aid. With the development of information technology, the production mode and management idea of traditional manufacturing industry have undergone a series of revolutionary changes, which greatly enhances the competitiveness of manufacturing industry in northeast China. In spite of this, we also have to admit that there still exists many problems compared to national and even foreign manufacturing informatization technology.

\section{II、The informatization of the manufacturing industry in northeast China}

\section{(One) The leaders has a weak cognition awareness of informatization.}

The leaders in some enterprises don't have a deep understanding of the purpose and significance of informatization, directly influencing their decisions. Firstly, enterprises leaders attach too much importance to the informatization itself but ignore the introduction of advanced management thought and management mode. In fact, enterprise informatization is just a process of introducing advanced management model and management idea suitable for its development. Secondly, enterprises leaders often delegate the task to related departments. So the cooperative software companies or institutions of higher learning even think they are chief designer of informatization. Only the enterprise management has an overall understanding about the historical situation and the future development of the enterprise and has a clear acquaintance about the existing resources condition and management process of the enterprise.

\section{(Two) The informatization structure foundation is weak.}

Most of the enterprises didn't do a good job in the informatization infrastructure, which also has made the huge difficulties for later enterprise informatization construction. The basis of the informatization structure construction not only includes establishing a standard unified coding for all kinds of resources in the enterprise, but also ensure a regulate, smooth and stable information collection channels and means. At the same time, it needs to study the scientific, reasonable and in-depth machining process on information. Many experiences and lessons prove that the failure reason of information system is not in the technical means and methods but in the basic job of informatization structure management itself.

\section{(Three) There is a lack of talents to maintain and develop informatization.}

The characteristic of manufacturing enterprises is order-oriented small batch production, which means it don't have a fixed line or a specific production process. However, the manufacturing industry in Northeast China is the specific product under the planned economy system in China, featuring unreasonable structure and product structure, backward product technology and weak market competition. In addition, most of them got into trouble in the process of reform and opening up, which caused enormous outflow of talents. At the same time, because of the mechanism and region and the lack of a sound environment for attracting talents, this makes the enterprise struck into the situation of serious lack of talents and some even have no special informatization talents.

\section{(Four) The input of informatization is not in direct proportion to its benefit.}

Most companies think enterprise informatization is a one-time investment and the informationization implementation can succeed once and for all. In fact, almost all of the informatization have to undergo system upgrade process after early success, taking huge funds. Whether the rewards of informatization system can offset the increased cost of the system will surely bring huge economic risk for the enterprise, so the enterprise must have a clear understanding about this before the implementation of informatization. Because there is no specific index quantitative system and the enterprise ignored the stub and analysis of the data, it caused a vicious circle. 


\section{III、The informationization countermeasures of the manufacturing industry in Northeast}

\section{China}

Under the support of the state informationization construction, the Northeast China has taken the development path of informatization and manufacturing integration to realize the revival of the manufacturing industry in Northeast China. According to the results of this study, in the development path of informatization and manufacturing integration, the Northeast China has to do the following points:

(One) Give full play to the government's macroeconomic regulation and control function

The transformation essence of the manufacturing industry in Northeast China is the reshaping process of industrial base and should be the result of market selection. Depending entirely on the market spontaneous regulation at present stage can't achieve the transformation goal in a short time, so the current transformation essence of the manufacturing industry in Northeast China is government action. So, in the process of reconstructing the manufacturing industry in Northeast China, the government should give priority to with indirect regulation and had better not bother with the specific construction of enterprise informatization. It should put more efforts on the function of service and supervision, strengthen the construction of public information infrastructure, increase investment in informatization construction, introduce competition mechanism and expand investment channels.

\section{（Two） Use informatization development to promote manufacturing industry}

The informatization construction of the manufacturing industry in Northeast China should be implemented in different phases and keys rather in only one phase. In the process of advancing informatization and manufacturing integration, we must firstly choose the pillar industry to do the informatization transform in order to drive the upgrading of other traditional industries. To transform the traditional industry by informatization, the Northeast China must achieve the informatization of manufacturing industry. It should apply high and advanced technology to transform the manufacturing industry and integrate the information technology and enterprise product to realize product innovation.

\section{(Three) Insist on education first and use education informatization drive manufacturing industry}

In order to achieve informatization transform traditional industry and realize the industry upgrading, it requires corresponding high-quality workforce. The gain of high quality of the labor force is the result of modern education while the two main forces determining the 21st century are: the first the Internet and the second education. In the process of education, we should comprehensively apply modern information technology based on computer multimedia and network communication to promote the comprehensive reform of education, so as to adapt it to the new requirements information society on education development. In addition, we should carry out extensive information education in the whole society, improve the degree of the popularity of computer and network application and strengthen the development and utilization of information resources.

\section{(Four) Strengthen the development and utilization of information resources}

According to the condition of the manufacturing industry in Northern China, the development and utilization of information resources should put the principle of less investment, high efficiency, advanced technology and unified planning. The development speed should keep pace with the construction of information infrastructure, growth of information resources and the change of user requirements. At the same time, we should strengthen the macroeconomic regulation and control of 
information resources development to avoid re-handling duplication of labor. In addition, the focus of the information resources development and service should be given priority to enterprise and emphasizes the function of the service for the enterprise competition, in order to provide enterprises with the control and decision information in the process of production, operation, decision-making and management, and the information required by the enterprises in market.

\section{IV、Conclusions}

The informatization research on the manufacturing industry in northern China should accelerate the development of information industry, making the information industry become an important growth point of northeast economy. We should use the informatization technology of manufacturing industry to transform traditional industry, promote industrial structure optimization and improve the competition ability and development ability in northern China. In the future, we should focus on developing the informatization research of manufacturing industry supporting the national economic and technological upgrading, forming a new road on which informatization promotes the development of manufacturing industry.

\section{References}

[1] Yu Zongshui, The Basic Way of Revitalizing the Old Industrial Base of the Northeast Is to Take the New-type Industrialized Road,[J], The Journal of Liaoning Education Administration Institute,2006 (6): 56-57.

[2]Hu Jintao, The Report on the 17th National Congress of the Communist Party of China[R]. 2007. [3]Sui Duo, China's Regional Economic Development Report:The Revival Study of the Northeast Old Industrial Base[M].Beijing:Hongqi Press,2004: 398 -402.

[4]Pan Yurui, Accelerate the Revitalization of the Northeast Old Industrial Base by Informatization Research[J]. The Journal of Liaoning Administration Institute,2004, (1): 48- 49.

[5]Feng Deren, Who Is Hampering the Enterprise Information[J]. Business Management, 1998, ( 7): 46. 